University of Nebraska - Lincoln

DigitalCommons@University of Nebraska - Lincoln

Papers in Entomology

Museum, University of Nebraska State

November 2000

\title{
The use of live-bait traps for the study of sylvatic Rhodnius populations (Hemiptera: Reduviidae) in palm trees
}

\author{
F. Abad-Franch \\ Pathogen Molecular Biology and Biochemistry Unit, Department of Infectious and Tropical Diseases, \\ London School of Hygiene and Tropical Medicine, Keppel Street, London WC 1E 7HT, UK \\ F. Noireau \\ Institut de Recherche pour le Developpement (IRD) and Instituto Oswaldo Cruz, Laboratório Nacional e \\ Internacional de Referênda em Taxonomia de Triatomíneos, avenida Brasil 4365, 21045-900 Rio de \\ Janeiro, Brazil \\ A. Paucar C. \\ University of Nebraska - Lincoln \\ H. M. Aguilar V. \\ Unidad de Medicina Tropical, Instituto 'Juan Cesar Garcia,' CP 17-1106292 Quito, Ecuador \\ C. Carpio C. \\ Unidad de Medicina Tropical, Instituto 'Juan Cesar Garcia,' CP 17-1106292 Quito, Ecuador \\ See next page for additional authors
}

Follow this and additional works at: https://digitalcommons.unl.edu/entomologypapers

Part of the Entomology Commons

Abad-Franch, F.; Noireau, F.; Paucar C., A.; Aguilar V., H. M.; C., C. Carpio; and Racines V., J., "The use of live-bait traps for the study of sylvatic Rhodnius populations (Hemiptera: Reduviidae) in palm trees" (2000). Papers in Entomology. 129.

https://digitalcommons.unl.edu/entomologypapers/129

This Article is brought to you for free and open access by the Museum, University of Nebraska State at DigitalCommons@University of Nebraska - Lincoln. It has been accepted for inclusion in Papers in Entomology by an authorized administrator of DigitalCommons@University of Nebraska - Lincoln. 


\section{Authors}

F. Abad-Franch, F. Noireau, A. Paucar C., H. M. Aguilar V., C. Carpio C., and J. Racines V. 
Published in Transactions of The Royal Society of Tropical Medicine and Hygiene 94:6 (November/December 2000), pp. 629-630. Copyright (C 2000 Royal Society of Tropical Medicine and Hygiene; published by Elsevier. Used by permission. http://www.sciencedirect.com/science/journal/00359203

\title{
The use of live-bait traps for the study of sylvatic Rhodnius populations (Hemiptera: Reduviidae) in palm trees
}

\author{
F. Abad-Franch ${ }^{1,3, *}$, F. Noireau ${ }^{2}$, A. Paucar C. ${ }^{\dagger}$, H. M. Aguilar V. ${ }^{3,4}$, C. Carpio C. ${ }^{3}$, and J. Racines V., \\ ${ }^{1}$ Pathogen Molecular Biology and Biochemistry Unit, Department of Infectious and Tropical Diseases, London School of Hygiene and Tropical Medicine, \\ Keppel Street, London WC 1E 7HT, UK \\ ${ }^{2}$ Institut de Recherche pour le Developpement (IRD) and Instituto Oswaldo Cruz, Laboratório Nacional e Internacional de Referênda em Taxonomia de \\ Triatomíneos, avenida Brasil 4365, 21045-900 Rio de Janeiro, Brazil \\ ${ }^{3}$ Unidad de Medicina Tropical, Instituto ‘Juan Cesar Garcia,' CP 17-1106292 Quito, Ecuador \\ ${ }^{4}$ Instituto Nacional de Higiene y Medicina Tropical 'Leopoldo Izquieta Pérez’ Zona Norte, Iquique 2045 y Yaguachi, Quito, Ecuador \\ * Corresponding author, email fernando.abad-franch@1shtm.ac.uk \\ ${ }^{\dagger}$ Current address: Systematics Research Collections, W-436 Nebraska Hall, University of Nebraska State Museum, Lincoln, NE 68588-0514, USA. \\ \$Deceased in December 1999.
}

Keywords: Rhodnius, sylvatic populations, trapping, palm trees, methodology, Ecuador

Chagas disease is a major public health challenge for most Latin American countries. An initiative for the coordinated control of Chagas disease transmission throughout the Andean countries was launched in 1997. Since the early 1990s, control measures based on elimination of domestic/peridomestic triatomine colonies and screening of donor blood by serological testing have resulted in a reduction in incidence of $\sim 70 \%$ in the Southern Cone countries (WHO, 1991; Dias \& Schofield, 1999; Moncayo, 1999; WHO/CTD, 2000).

Various Rhodnius species are among the most important vectors of Trypanosoma cruzi, the causative agent of Chagas disease, in different countries of continental South and Central America. All of them have been reported to breed in arboreal habitats and many of them in palm trees of different genera (Whitlaw \& Chaniotis, 1978; Lent \& Wygodzinsky, 1979; Miles et al., 1983; Pizarro \& Romaña, 1998). The study of the ecological traits and behavioral trends of sylvatic populations is a key to the understanding of the processes leading to the initial colonization of human dwellings by Rhodnius species, and recolonization following vector control interventions (Dujardin et al., 1991; Costa, 1999).

$R$. ecuadoriensis is a major vector of Chagas disease in Ecuador, and is able to colonize human-related habitats by migration from sylvatic ecotopes (Lent \& Wygodzinsky, 1979; Romaña et al., 1994; Schofield, 1994; Aguilar et al., 1999). Sylvatic populations of $R$. ecuadoriensis have been reported to occur in central and northern coastal regions, in palm trees of the genus Phytelephas (locally known as palma de tagua, used for handicraft manufacture and frequently maintained in the peridomicile) (Avilés et al., 1995; Borchsenius et al., 1998). Here we report preliminary results of the use of live bait traps in the study of sylvatic Rhodnius populations in Ecuador.

The direct collection of sylvatic Triatominae is time consuming and logistically difficult. Results are usually scarce, even when dissection of natural ecotopes (e.g., palm trees) is undertaken (Miles et al., 1981; Pizarro \& Romaña, 1998). Light trapping is also of limited value, as only starved adults of few species fly readily to light traps. Several authors have reported the use of animal-baited traps for triatomines (Rabinovich et al., 1976; Tonn et al., 1976; Carcavallo, 1985), all as yet with poor results. Recently, Noireau et al. $(1999,2000)$ described a simple trapping system that produced excellent results in the study of sylvatic Triatoma (T. sordida, T. guasayana, and T. infestans dark morph) inhabiting hollow trees in the Bolivian Chaco. The system consists of a small plastic bottle containing a mouse as bait and covered with double-coated adhesive tape. We have applied this method, introducing several modifications aimed to improve its performance and the welfare of the mouse, to study sylvatic Rhodnius populations in palm trees in Ecuador.
The study area, nearby the locality of Alluriquín (province of Pichincha), is located on the western slope of the Andes (700-800 m above sea level; approximately $79^{\circ} 00^{\prime} \mathrm{W}, 00^{\circ} 20^{\prime} \mathrm{S}$ ). The area comprises very humid subtropical forest (Cañadas, 1983). Phytelephas aequatorialis Spruce, a palm tree endemic to the Ecuadorian western slope of the Andes (Borchsenius et al., 1998), is abundant in the zone, and was suspected of being a favored ecotope for Rhodnius insects. Our modified traps consisted of a plastic container, larger $(\sim 15 \times 9 \mathrm{~cm})$ than those used by Noireau et al. (1999), in which a mouse was contained together with a small quantity of wood shavings and food (aiming to protect the animal from low night temperatures and starvation). Small holes were made in the lower side of the bottles so that water from rain could not accumulate within. Containers were closed with $1 \mathrm{~mm}$-aperture wire mesh and wrapped around with double-coated adhesive tape. They were located in different parts of the palm trees (among epiphytes growing around stems, or directly in the angle between palm fronds and the stem). Our objectives were: (i) to test the performance of modified live-bait traps in palm trees, and with Rhodnius species; (ii) to detect positive palm trees for further studies; and (iii) to capture some live specimens for laboratory studies. We initially studied 11 P. aequatorialis palm trees by direct searches for insects in their crowns. In a second attempt, we investigated 34 palm trees using the modified traps (placed overnight on the palms). We used a total of 56 trap-nights on these palms. We also undertook a manual capture of insects in the organic matter and epiphytes present around the trunk of 1 palm tree. Part of these materials were cut down and examined on a white sheet (4 people searching during $3 \mathrm{~h}$ ). Finally, we dissected another palm by cutting it down and systematically inspecting it on a larger white sheet $(4$ people, $3 \mathrm{~h}$ ). These 2 palms were already known to be positive (triatomines were captured previously in live-bait traps).

Direct searches in palm crowns yielded negative results. By live-bait trapping, 12 out of 34 palm trees were found to be positive (infestation index $35.3 \%$ ) for the presence of Rhodnius breeding colonies (nymphs captured, colonisation index 100\%) [insects were preliminarily identified as R. ecuadoriensis as described by Lent \& Wygodzinsky (1979); molecular taxonomy studies are ongoing]. Of 56 trap-nights, 27 (48\%) were found to be positive (containing triatomine bugs adhered to the tape) when checked the following morning. The average number of insects per positive trap-night was 4.9 , with a maximum of 14 individuals in a single trap-night. We captured a total of 141 Rhodnius insects. The crowding index (average number of insects per positive palm) was 11.75 , and the density index (insects captured/palms examined) was 4.15 . Of the total number, 139 bugs (99\%) were nymphs of different stages, with just 2 adults ( 1 female and 1 male) (adults/nymphs index 0.014 ). Seven nymphs 
were captured in 2 positive palms by other means, with just 1 fifth-instar nymph captured by complete dissection of 1 of these palms. No other triatomine species was found.

The performance of modified live-bait traps in this study is notably better than reported in 1999 and 2000 by Noireau et al. (48\% positive against $27 \%$ and $21.9 \%$ positive, respectively); these differences maybe related to the distinct triatomines and ecotopes studied (thus not necessarily to a superior trap design), but clearly reveal that this method yields excellent results in palms inhabited by Rhodnius. We recently captured 50 Rhodnius individuals ( $R$. pictipes and $R$. robustus) in a single trap-night in a P. tenuicaulis palm in the Ecuadorian Amazon (F. S. Palomeque et al., unpublished). Regarding palm dissection, in 25 published studies (cf. Pizarro \& Romaña, 1998) 1,390 palms were cut down and 10,564 Rhodnius were captured (an average of 7.6 insects/palm); our results in Pichincha (4.15 insects/palm, this report), and more widely in Ecuador (6.3 insects/palm by live-bait trapping plus direct searches in palm crowns, F. Abad-Franch et al., unpublished) question the necessity of indiscriminately cutting down and dissecting palms for this kind of study. The adults/nymphs index we found is very low (0.014), we speculate that adult insects may be able to escape from the adhesive tape, but a lower number of adults in sylvatic colonies - compared to that of immature individuals - may also be a reason. Previous studies (conducted by palm dissection, thus probably biased towards bigger insects) report an average adults/nymphs index of 0.7, range 0-2.6 (cf. Pizarro \& Romaña, 1998). With the live-bait traps, no mouse mortality was recorded, and animals spending the night inside the modified traps were found to be in perfect condition (except for 1 mouse, which was attacked by small ants, avoidable by covering the wire mesh with finer cloth).

Our results strongly suggest that live-bait traps with adhesive tape could be extremely helpful in the study of sylvatic populations of different Rhodnius and other Triatominae species associated with palm trees in the wild. This method provides a quick and inexpensive way to readily detect positive palm trees, and could be also of value for disease transmission control purposes, as the presence of triatomines in peridomestic palms may be easily monitored using live-bait traps. The ecological impact of cutting down and dissecting palm trees to study wild triatomines could be reduced to the minimum (and, in many cases, avoided), as could the effort required for such studies. Additionally, it is possible to recover sufficient live specimens to establish laboratory colonies and enlarge reference collections for further studies and comparisons.

\section{Acknowledgements}

This study was supported by the United Nations Development Programme/World Bank/WHO Special Programme for Research and Training in Tropical Diseases (Grant 970195), the ECLAT Network, and, partially, by the Tropical Medicine Unit (University General Hospital of Valencia, Spain), and the Canada-Blanch Foundation (Valencia, Spain). Special thanks are due to Michael A. Miles and Christopher J. Schofield for guidance and review of the manuscript, and to Dr Ana Abad-Franch for her suggestions and help during fieldwork.

\section{References}

Aguilar, V. H. M., Abad-Franch, F., Racines, V. J., \& Paucar, C. A. (1999). Epidemiology of Chagas disease in Ecuador. A brief review. Memorias do Institute Oswaldo Cruz, 94 (supplement 1), 387-393.

Avilés, H., Cevallos, P., Champaloux, B., Goujon, C., Lema, F., Pajony, R., Pays, J. F., Racines, V. J., \& Romaña, C. A. (1995). Rhodnius ecuadoriensis en areas endemicas de tripanosomiasis americana en Ecuador. Parasitologia al Día, 19 (no. extraordinario), 231.

Borchsenius, F., Borgtoft Pedersen, H., \& Balslev, H. (1998). Manual to the Palms of Ecuador. Aarhus, Denmark: Department of Systematic Botany, Aarhus University-Pontificia Universidad Católica del Ecuador, Quito. AAU Reports 37.

Cañadas, L. (1983). Mapa Bioclimático y Ecológico del Ecuador. Quito, Ecuador: MAG-PRONAREG.
Carcavallo, R. U. (1985). Técnicas de estudio de triatominos en ambiente silvestre. In: Factores Biológicos y Ecológicos en la Enfermedad de Chagas, volume I, Carcavallo, R. U., Rabinovich, J. E., \& Tonn, R. J. (editors). Buenos Aires: OPS-ECO/MSAS-SNCH, pp. 49-52.

Costa, J. (1999). The synanthropic process of Chagas disease vectors in Brazil, with special attention to Triatoma brasiliensis Neiva, 1911 (Hemiptera, Reduviidae, Triatominae). Population, genetic, ecological and epidemiological aspects. Memorias do Institute Oswaldo Cruz, 94 (supplement 1), 239-241.

Dias, J. C. P. \& Schofield, C. J. (1999). The evolution of Chagas disease (American trypanosomiasis) control after 90 years since Carlos Chagas discovery. Memórias do Instituto Oswaldo Cruz, 94 (supplement 1), 103-121.

Dujardin, J. P., Garcia-Zapata, M. T., Jurberg, J., Poelants, P., Cardozo, L., Panzera, F., Dias, J. C. P., \& Schofield, C. J. (1991). Which species of Rhodnius is invading houses in Brazil? Transactions of the Royal Society of Tropical Medicine and Hygiene, 85, 679-680.

Lent, H. \& Wygodzinsky, P. (1979). Revision of the Triatominae (Hemiptera: Reduviidae), and their significance as vectors of Chagas disease. Bulletin of the American Museum of Natural History, 163, 123-520.

Miles, M. A., de Souza, A. A., \& Povoa, M. (1981). Chagas disease in the Amazon basin: III. Ecotopes of ten triatomine bugs species (Hemiptera: Reduviidae) from the vicinity of Belém, Pará State, Brazil. Journal of Medical Entomology, 18, 266-278.

Miles, M. A., Arias, J. R., \& de Souza, A. A. (1983). Chagas disease in the Amazon basin: V. Periurban palms as habitats of Rhodnius robustus and Rhodnius pictipes - triatomine vectors of Chagas disease. Memórias do Instituto Oswaldo Cruz, 78, 391-398.

Moncayo, A. (1999). Progress towards interruption of transmission of Chagas disease. Memórias do Instituto Oswaldo Cruz, 94 (supplement 1), 401-404.

Noireau, F., Flores, R., \& Vargas, F. (1999). Trapping sylvatic Triatominae (Reduviidae) in hollow trees. Transactions of the Royal Society of Tropical Medicine and Hygiene, 99, 13-14.

Noireau, F., Flores, R., Gutierrez, T., Abad-Franch, F., Flores, E., \& Vargas, F. (2000). Natural ecotopes of Triatoma infestans dark morph and other sylvatic triatomines in the Bolivian Chaco. Transactions of the Royal Society of Tropical Medicine and Hygiene, 94, 23-27.

Pizarro, J. C. N. \& Romaña, C. (1998). Variación estacional de una población silvestre de Rhodnius pallescens Barber 1932 (Heteroptera: Triatominae) en la costa Caribe colombiana. Bulletin de l'Institut François d'Etudes Andines, 27, 309-325.

Rabinovich, J. E., Carcavallo, R. U., \& Barretto, M. P. (1976). Ecologic methods: marking, trapping and sampling for vector studies in the field. In: New Approaches in American Trypanosomiasis Research, Washington: Pan American Health Organization, Scientific Publication no. 318, pp. $16-20$.

Romaña, C. A., Racines, V. J., Avilés, H., \& Lema, F. (1994). Observaciones de domiciliacion de Rhodnius ecuadoriensis en focos endémicos de la enfermedad de Chagas en el Ecuador. Microbiología, 1, 59.

Schofield, C. J. (1994). Triatominae: Biología y Control. West Sussex, UK: Eurocommunica Publications.

Tonn, R. J., Carcavallo, R. U., Ortega, R., \& Carrasquero, B. (1976). Metodos de estudio de triatominos en el medio silvestre. Boletin de la Dirección de Malariología y Saneamiento Ambiental, 16, 146-152.

Whitlaw, J. T. Jr \& Chaniotis, B. N. (1978). Palm trees and Chagas disease in Panama. American Journal of Tropical Medicine and Hygiene, 27, 873-881.

WHO (1991). Control of Chagas Disease. Geneva: World Health Organization, Technical Report Series, no. 811.

WHO/CTD (2000). World Health Organization: Chagas Disease; formerly http://www.who.int/ctd/chagas ; presently http://www.who. int/topics/chagas disease/en/ 